\title{
Walrus areas of use in the Chukchi Sea during sparse sea ice cover
}

\author{
Chadwick V. Jay ${ }^{1, *}$, Anthony S. Fischbach ${ }^{1}$, Anatoly A. Kochnev ${ }^{2}$ \\ ${ }^{1}$ US Geological Survey, Alaska Science Center, 4210 University Drive, Anchorage, Alaska 99508, USA \\ ${ }^{2}$ Pacific Research Fisheries Center, Chukotka Branch, Otke 56 Box 29, Anadyr, Chukotka 689000, Russia
}

\begin{abstract}
The Pacific walrus Odobenus rosmarus divergens feeds on benthic invertebrates on the continental shelf of the Chukchi and Bering Seas and rests on sea ice between foraging trips. With climate warming, ice-free periods in the Chukchi Sea have increased and are projected to increase further in frequency and duration. We radio-tracked walruses to estimate areas of walrus foraging and occupancy in the Chukchi Sea from June to November of 2008 to 2011, years when sea ice was sparse over the continental shelf in comparison to historical records. The earlier and more extensive sea ice retreat in June to September, and delayed freeze-up of sea ice in October to November, created conditions for walruses to arrive earlier and stay later in the Chukchi Sea than in the past. The lack of sea ice over the continental shelf from September to October caused walruses to forage in nearshore areas instead of offshore areas as in the past. Walruses did not frequent the deep waters of the Arctic Basin when sea ice retreated off the shelf. Walruses foraged in most areas they occupied, and areas of concentrated foraging generally corresponded to regions of high benthic biomass, such as in the northeastern (Hanna Shoal) and southwestern Chukchi Sea. A notable exception was the occurrence of concentrated foraging in a nearshore area of northwestern Alaska that is apparently depauperate in walrus prey. With increasing sea ice loss, it is likely that walruses will increase their use of coastal haul-outs and nearshore foraging areas, with consequences to the population that are yet to be understood.
\end{abstract}

KEY WORDS: Odobenus rosmarus · Foraging · Kernel density $\cdot$ Climate change $\cdot$ Utilization

Resale or republication not permitted without written consent of the publisher

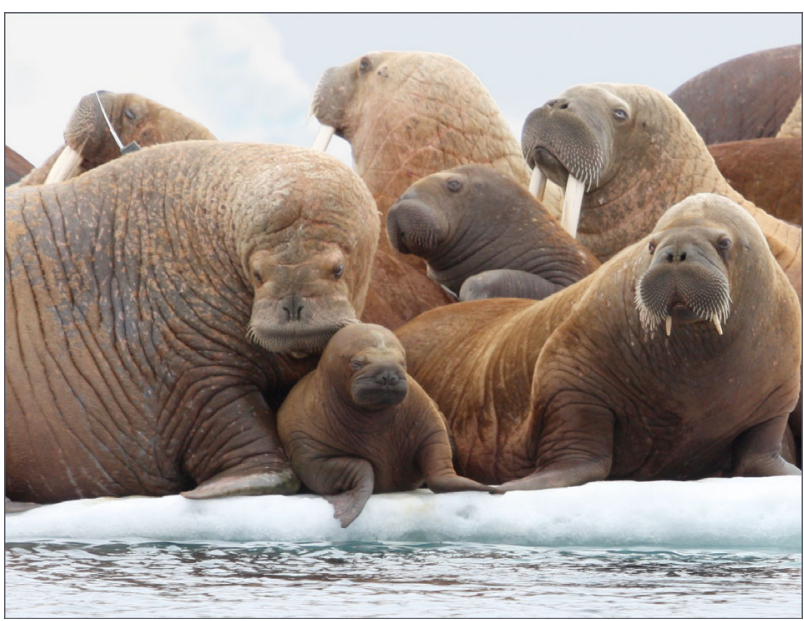

Adult female and young Pacific walruses Odobenus rosmarus divergens resting on sea ice during summer in the Chukchi Sea. Walrus at front left has a radio tag attached.

Photo: Sarah Sonsthagen (US Geological Survey)

\section{INTRODUCTION}

The extent of Arctic sea ice has declined since the late 19th century, with a pronounced decline over the last 3 decades (Polyak et al. 2010). From 1979 to 2011, the September minimum sea ice coverage declined by an average of $12 \%$ per decade (http://nsidc.org/ data/seaice_index/). In the last 5 yr (2007 to 2011), September sea ice minimums were at their lowest extent in satellite records (http://nsidc.org/data/ seaice_index/), marking a recent sequence of extreme summer ice minimums (Wang \& Overland 2009, Polyak et al. 2010), and possibly reflecting a growing non-linear response in ice loss from external climate forcing (Stroeve et al. 2011). 
The continued loss of summer sea ice is projected to affect the distribution of marine mammals (Tynan \& DeMaster 1997, Laidre et al. 2008, Kovacs et al. 2010), including the Pacific walrus Odobenus rosmarus divergens in the Chukchi Sea (Kochnev 2004, Jay et al. 2011). Simultaneously, projected reductions in ice extent and thickness and increases in the frequency and duration of ice-free periods in the Chukchi Sea (Kwok \& Rothrock 2009, Wang \& Overland 2009, Douglas 2010, Stroeve et al. 2011) will likely result in a rise in human activities in the region, which could further affect walrus movement patterns. Current details on walrus distribution and important foraging areas in the Chukchi Sea are needed to better understand how walruses are responding to climate change, and are vital for resource managers to effectively mitigate the influence of human activities on walruses.

Walruses frequently haul out onto ice to rest between foraging trips and, in certain seasons, to bear their young and molt. They require ice floes large enough to support their weight, but avoid areas with very high concentrations of thick ice where their movements in water may become restricted (Fay 1982).

The Pacific walrus migrates between the Chukchi and Bering Seas with the seasonal melting and accretion of sea ice each year. Prior to our study, the seasonal migration patterns of walruses were known primarily from Fay's (1982) compilation of published and unpublished records of walrus sightings from land, ship, and aircraft from 1930 through 1979 (50 yr). This information was updated slightly by Fay et al. (1984) with observations from the Chukchi Sea in summer to fall of 1981 to 1983. These observations of walrus migration patterns were made prior to the beginning of pronounced declines in Arctic sea ice.

In general, after wintering in the Bering Sea, walruses would enter the Chukchi Sea in May with the formation of open leads in sea ice north of the Bering Strait and a major ice flaw along the northwestern coast of Alaska and northern Chukotka (Fig. 1) (Fay 1982, Fay et al. 1984). In June, an additional flaw formed along the northern coast of Chukotka. At this time, most females and young, and a small number of subadult and adult males, moved northward through the flaw zones. From July through August, walruses continued to move northward into the eastern Chukchi Sea and west through Long Strait and northwestward into waters near Wrangel Island in the western Chukchi Sea (Fay 1982, Fay et al. 1984).

As sea ice retreated to its most northern extent in September, walruses occurred along the ice edge over the continental shelf, mainly to the east of $170^{\circ} \mathrm{W}$ and to the west of Herald Island $(70 \mathrm{~km}$ east of Wrangel Island) (Fay 1982, Fay et al. 1984). In years when the ice edge retreated far to the north, walruses in the western Chukchi Sea often hauled out in large numbers on Wrangel Island (Fay 1982).

In October, walruses migrated southward with the rapid formation of sea ice and, by November, most of the population occurred south of the Bering Strait. Southward migration patterns in fall are poorly known, but observations suggest that walruses summering in the Chukchi Sea converged on the northern coast of Chukotka before moving southeastward toward the Bering Strait (Fay et al. 1984).

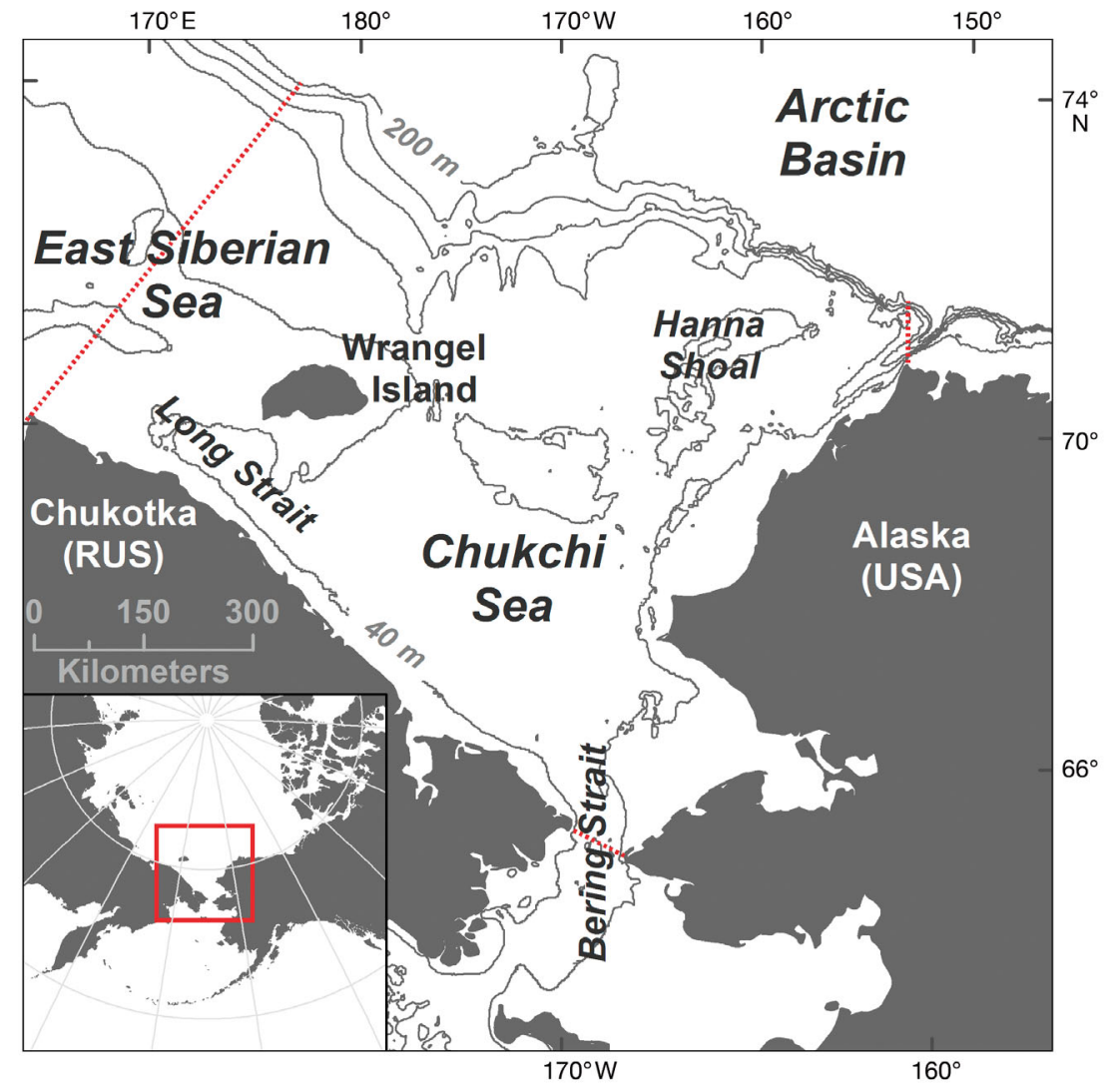

Fig. 1. Study area encompassing estimates of utilization distributions of walrus Odobenus rosmarus divergens foraging and occupancy in the Chukchi Sea, 2008 to 2011. Red dotted lines and the $200 \mathrm{~m}$ isobath delineate the boundaries used for the sea ice summaries for 2007 to 2011 and 1979 to 1988 (see Fig. 6) 
Walruses feed on benthic invertebrates across large areas of the continental shelf. Analyses of the contents of walrus stomachs collected across areas of the Bering and Chukchi Seas suggest that the most frequently consumed prey are bivalves, gastropods, and polychaetes (Sheffield \& Grebmeier 2009). Fay et al. (1977) postulated that walruses mainly depend on a few gregarious prey types that can be fed upon efficiently (such as large bivalves) and that occur in patches of high caloric biomass. One such feeding area of high prey biomass in the eastern Chukchi Sea is Hanna Shoal (Dunton et al. 2005, Grebmeier et al. 2006), where walruses have been observed in large numbers between July and October (Fay et al. 1984, Brueggeman et al. 1992). Judging by the concentration of walrus sightings in the western Chukchi Sea between July and October (Fay 1982, Fay et al. 1984), offshore areas of northern Chukotka, Long Strait, and Wrangel Island are also likely to encompass dense patches of walrus prey.

With recent (2007 to 2011) changes in Arctic sea ice, patterns of walrus migration and areas of use have changed. Here, we use walrus telemetry data from the Chukchi Sea to delineate areas of walrus foraging and occupancy during summer and fall (June to November) of 2008 to 2011, years when walruses experienced sparse sea ice over the continental shelf. These observations provide a first look at the response of walruses to sea ice change, and improve our ability to forecast how future sea ice changes could affect the distribution and abundance of the population (Jay et al. 2011).

\section{MATERIALS AND METHODS}

\section{Study area}

Our study area was primarily the Chukchi Sea and the eastern East Siberian Sea (Fig. 1), bounded to the north by the edge of the continental shelf (ca. $200 \mathrm{~m}$ isobath). The shelf is strongly influenced by the advection of nutrient-rich waters from the Pacific Ocean and sustains some of the highest benthic faunal soft-bottom biomass in the world. High primary production and low grazing pressure by zooplankton over the shallow shelf results in the deposition of high levels of organic material to the seafloor where it supports a rich benthic food web (Grebmeier et al. 2006).

\section{Walrus radio-tagging}

We attached satellite radio tags (Telonics) to walruses Odobenus rosmarus divergens resting on sea ice and beaches in the northern Bering Strait region and the Chukchi Sea in summer and fall (Fig. 2, Table 1). The tags were similar to the post-type tags described in Jay et al. (2006) and were usually deployed with a crossbow and sometimes with a jab stick. We attached the tags primarily to adult females. Although the sex ratio of adult walruses that occurs in the Chukchi Sea is unknown, field observations suggest that adult males are much less common there than females and young in summer and fall (Fay 1982), so we included only a small proportion of adult males in our sample of tagged walruses. Each

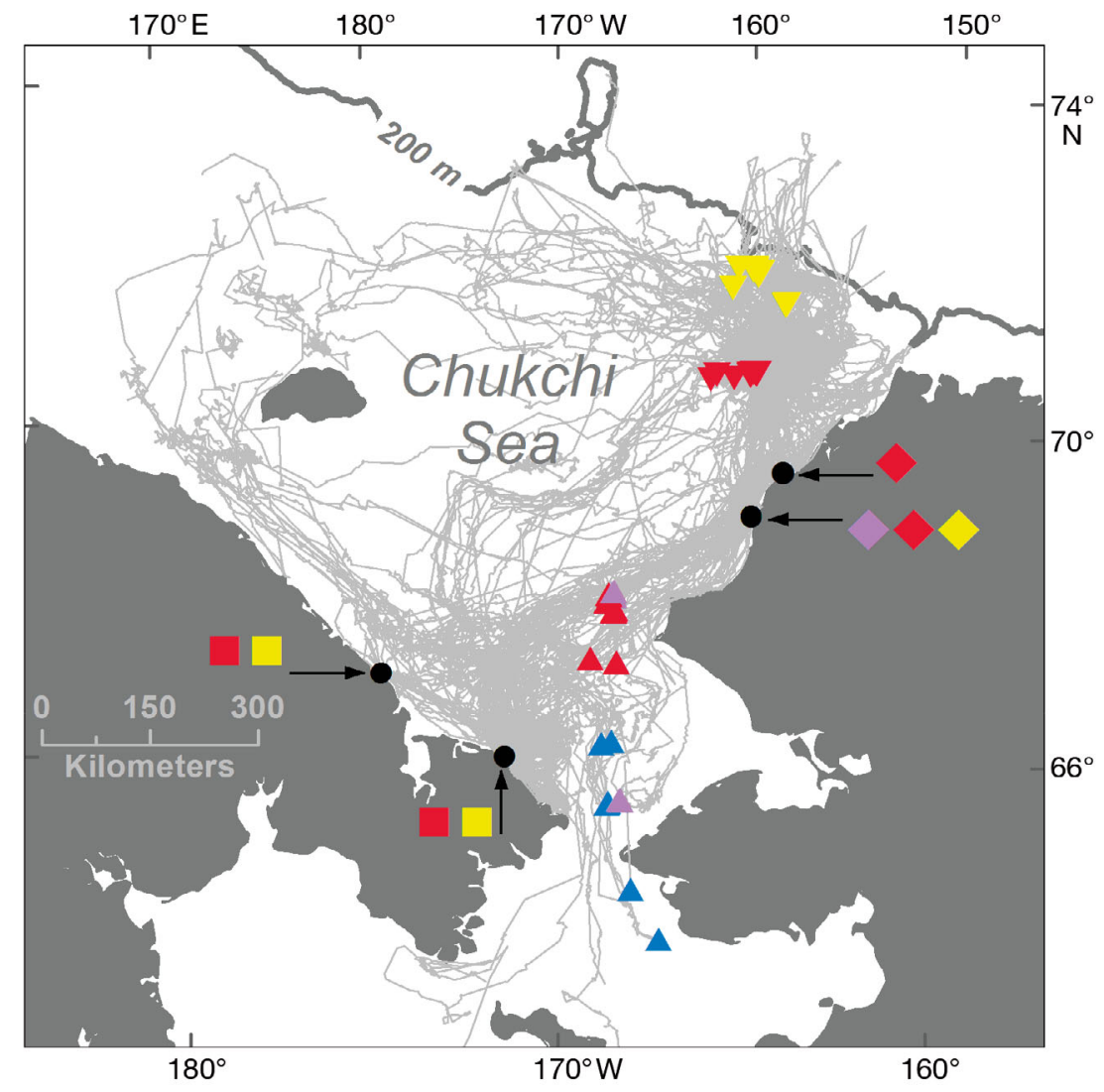

Fig. 2. Odobenus rosmarus divergens. Locations of radio-tag deployments on walruses used in utilization distribution estimates of walrus foraging and occupancy in the Chukchi Sea, 2008 to 2011 (see Table 1 for description of map symbols). Filtered movements of all walruses and years are indicated by gray track lines 
Table 1. Odobenus rosmarus divergens. Radio-tag deployment information for walruses used in utilization distribution estimates of walrus foraging and occupancy in the Chukchi Sea, 2008 to 2011. Symbols apply to Fig. 2; F: female; M: male; U: unidentified

\begin{tabular}{|c|c|c|c|c|c|c|c|}
\hline \multirow{2}{*}{$\begin{array}{l}\text { Deployment } \\
\text { location }\end{array}$} & \multirow{2}{*}{$\begin{array}{l}\text { Map } \\
\text { symbol }\end{array}$} & \multirow[t]{2}{*}{ Year } & \multirow{2}{*}{$\begin{array}{l}\text { Deployment } \\
\text { date }\end{array}$} & \multicolumn{4}{|c|}{ No. of walruses } \\
\hline & & & & Total & $\mathrm{F}$ & $\mathrm{M}$ & $\mathrm{U}$ \\
\hline \multirow{3}{*}{$\begin{array}{l}\text { Southern, } \\
\text { offshore }\end{array}$} & $\Delta$ & 2008 & 31 May-4 Jun & 15 & 12 & 2 & 1 \\
\hline & $\Delta$ & 2009 & 6-9 Jun & 33 & 31 & 0 & 2 \\
\hline & $\Delta$ & 2010 & 9-12 Jun & 39 & 31 & 8 & 0 \\
\hline \multirow{2}{*}{$\begin{array}{l}\text { Northeastern, } \\
\text { offshore }\end{array}$} & $\nabla$ & 2010 & 8-9 Jul & 31 & 29 & 1 & 1 \\
\hline & $\nabla$ & 2011 & 20-21 Jul & 36 & 26 & 4 & 6 \\
\hline \multirow{3}{*}{$\begin{array}{l}\text { Eastern, } \\
\text { onshore }\end{array}$} & $\diamond$ & 2009 & $16 \mathrm{Sep}$ & 6 & 6 & 0 & 0 \\
\hline & $\diamond$ & 2010 & 7-9 Sep & 17 & 14 & 1 & 2 \\
\hline & $\nabla$ & 2011 & 25-26 Aug & 32 & 31 & 0 & 1 \\
\hline \multirow{2}{*}{$\begin{array}{l}\text { Southwestern, } \\
\text { onshore }\end{array}$} & $1, \quad \square$ & 2010 & $30 \mathrm{Sep}-24 \mathrm{Oct}$ & 21 & 21 & 0 & 0 \\
\hline & 口 & 2011 & 6-21 Oct & 21 & 21 & 0 & 0 \\
\hline \multicolumn{4}{|l|}{ Total } & 251 & 222 & 16 & 13 \\
\hline
\end{tabular}

tag was fitted with a barbed head that embedded in the walrus's blubber layer on impact. We attempted to place each tag on the individual's dorsum, midway between the shoulders.

The sex of tagged walruses was classified either from sexually dimorphic features (Fay 1982, Fay \& Kelly 1989), the close attendance of a calf in the case of an adult female, or genetic determination of sex from remotely collected biopsies (Fischbach et al. 2008), which, when available, were considered the most reliable sex indicators. If we could not determine sex using one of these methods, we classified the sex of the animal as undetermined. Protocols for walrus tagging and associated activities were reviewed and approved by the US Geological Survey (USGS), Alaska Science Center Animal Care and Use Committee, and conducted under US Fish and Wildlife Service (USFWS) Permit No. MA801652-6.

We derived chronologies of the hourly haul-out and foraging state of tagged walruses from data collected by a conductivity sensor and pressure transducer on the radio-tag. Every second, the conductivity sensor indicated whether the tag was in or out of salt water and the pressure transducer indicated the depth of the tag. If $\geq 90 \%$ of the conductivity measurements within a $1 \mathrm{~h}$ interval indicated the tag was out of water, the walrus was considered to be hauled out during that interval. If $>50 \%$ of the pressure measurements within a $1 \mathrm{~h}$ interval indicated the tag was $>10$ m deep, the walrus was considered to be foraging during that interval. Thus, 1 of 3 behavioral states was possible for each $1 \mathrm{~h}$ interval: (1) hauled out, (2) in water and foraging, or (3) in water and not foraging.
We validated our foraging behavior classification criterion with a sample of $2084 \mathrm{~h}$ of detailed dive profile data acquired from time-depth recorders (TDR) on male walruses in waters over the continental shelf in a separate study (Jay et al. 2001). The study classified the dive profiles into 4 dive types, including a dive type associated with foraging. We delineated hourly intervals across the chronological sample of dive data and classified an interval as a foraging interval if $>50 \%$ of the 10 s TDR depth measurements in the interval was associated with foraging dives (identified in Jay et al. 2001). We compared the classification of each interval with the classification of the interval by our criterion and found that $98 \%$ of the 2084 interval classifications were concordant, indicating that our criterion accurately identified $1 \mathrm{~h}$ intervals that contained $>30 \mathrm{~min}$ of forage diving. Foraging dives have a median dive duration and inter-dive surface interval of 7.2 and $2.2 \mathrm{~min}$, respectively (Jay et al. 2001), which would equate to $46 \mathrm{~min}$ of forage diving in an hour of continuous foraging behavior. This suggests that our classification criterion identifies foraging intervals that are associated with a high degree of foraging.

The tag continuously recorded haul-out and foraging state. Data from 119 consecutive $1 \mathrm{~h}$ intervals were encoded in each transmission from the radiotag. By using a $1 \mathrm{~h}$ interval, the data from any given interval were received if at least 1 transmission was successfully received during the $5.0 \mathrm{~d}$ period the interval's data were stored onboard the tag. This provided considerable redundancy and allowed for collection of a nearly continuous chronology of haul-out and foraging states from each tagged walrus. To exclude data with transmission errors, we retained only data received from transmissions that passed an 8 bit cyclical redundancy checksum (Peterson \& Brown 1961) and that showed temporal continuity with data from previous or subsequent transmissions.

To conserve battery life, we programmed the tag to transmit for a period up to only $12 \mathrm{~h}$ each day, centered on local noon, and only when the tag was out of water. This transmission schedule, and the battery capacity of the tag, allowed for transmissions to occur for at least $12 \mathrm{wk}$. However, the longevity of deployed tags was considerably less than $12 \mathrm{wk}$; therefore, to obtain tracking data from walruses during the entire summer to fall period, we attached tags on walruses at various times and locations throughout the study months (June to November).

We received data and geographic location estimates from the Argos location and data collection system (Collecte Localisation Satellites 2011). Argos 
location estimates were filtered through the Douglas Argos-filter algorithm (Douglas et al. 2006), which uses spatial redundancy, movement rates, and angles to select between primary and alternate Argos locations and rejects unreasonable location estimates (see Udevitz et al. 2009 for user-defined filter settings).

\section{Walrus areas of use}

We estimated utilization distributions (UDs) using kernel methods (Kie et al. 2010). A UD describes an animal's probability of space use (activity or occupancy) at a point in space during a specified time period (Kernohan et al. 2001). A kernel UD estimate is generally reported as the smallest area that includes a specified proportion of the total estimated UD volume. For example, the $95 \%$ UD contour is the smallest area that contains $95 \%$ probability of use (Powell 2000, Kernohan et al. 2001).

Typically, a utilization distribution is defined by a grid of cells superimposed over the study area, and a mean kernel density is calculated for each cell (Powell 2000, Kernohan et al. 2001). The size and resolution of the grid has apparently little effect on the distribution estimate (Calenge 2012). We used a grid cell size of $5 \mathrm{~km}^{2}$ to partially account for spatial errors associated with Argos location estimates while allowing for relatively fine resolution of spatial structure on the scale of our study area. To minimize linear distortion of walrus movements, all data were projected into an azimuthal equidistant projection centered on the study area $\left(70^{\circ} \mathrm{N}, 170^{\circ} \mathrm{W}\right)$.

We used the Benhamou \& Cornélis (2010) movement-based kernel density estimator to estimate a UD of walrus foraging and, separately, a UD of walrus occupancy across the Chukchi Sea during each of the study months using the spatial analysis package adehabitatHR written in $\mathrm{R}$ (Calenge 2012). The movement-based kernel density estimator explicitly incorporates serially correlated animal locations and animal activity information by assuming that the probability of space use should distribute preferentially in the direction of a pair of successive locations (track segment) and interpolating intra-segment locations with a density proportional to the frequency of the activity during the segment. This contrasts with classical kernel estimators, which assume animal locations are independent and apply a uniform probability of space use around each location (Benhamou \& Cornélis 2010).

Tagged walruses provided zero to multiple locations per day. All locations were obtained within $6 \mathrm{~h}$ of local noon (GMT - $13 \mathrm{~h}$ for the center of the Chukchi Sea), because of the daily transmission schedule of the tag. To ensure that a sufficient number of $1 \mathrm{~h}$ behavior intervals were available to estimate the proportion of hours spent foraging during a track segment, we defined track segments as temporally bounded by local noon to local noon at least $24 \mathrm{~h}$ later. When available, we assigned a geographic location to each day's local noon with the highest quality Argos location within $4 \mathrm{~h}$ (preferred) or $6 \mathrm{~h}$ of local noon. Therefore, depending on the availability of daily locations, a track segment could be comprised of one to several $24 \mathrm{~h}$ increments.

During radio-tagging efforts, we often tagged groups of walruses within a relatively small geographic area, due to the logistical constraints of finding and accessing walruses offshore during brief periods of favorable weather. To minimize geographic bias associated with a tagging area, we excluded data that were obtained within $4 \mathrm{~d}$ of the time a walrus was tagged. We selected this exclusion period because the movement of radio-tagged walruses from 2 tagging areas in 2011 in the Chukchi Sea that were separated by $\sim 50 \mathrm{~km}$ indicated the tagged walruses spatially intermingled within about $3 \mathrm{~d}$ after the time the radio-tags were deployed (USGS, Alaska Science Center, unpubl. data).

To estimate a UD of foraging in a month, we estimated, for each walrus, a UD for each track segment, then summed the UD volume within each grid cell across all track segments with the volume from each track segment multiplied by the proportion of hours spent foraging during the track segment, and then re-scaled each cell volume so that the total volume within the study area summed to 1 . Kernel density estimation assumes smooth transitions in location densities, and therefore abrupt changes in space use from a boundary that blocks animal movements, such as land in the case of walruses, will result in biased density estimates in the vicinity of both sides of the boundary (Benhamou \& Cornélis 2010). The movement-based kernel density estimator includes a method to derive unbiased estimates of occupancy in grid cells close to a boundary that blocks animal movements; however, we were unable to apply this method, because of the tortuosity of the complex Chukchi Sea coastline. Therefore, within a month, we restricted kernel density estimates to marine areas by eliminating kernel volumes over land and re-scaling the total kernel volume for each walrus to 1. Subsequently, we summed the UD volume within each cell across all walruses with the volume from each walrus multiplied by the proportion of days tracked during 
the month and re-scaled each cell volume so that the total volume within the study area summed to 1.

In addition to estimating monthly UDs of walrus foraging, we estimated monthly UDs of walrus occupancy by following the above procedure, but without weighting each track segment by number of hours spent foraging. In this way, the UD estimation procedure (Benhamou \& Cornélis 2010) applied equal weighting between the 2 locations of each track segment without regard to foraging activity. Parameter settings that we used for user-defined variables in adehabitatHR (Calenge 2012) to estimate UDs are described in Appendix 1.

We characterized the monthly degree of overlap between areas of foraging and areas of occupancy using the volume of intersection (VI) index function (kerneloverlap) available in adehabitatHR (Calenge 2012). The VI index provides a single measure of overlap that is a function of the full UDs, in this case foraging and occupancy, and ranges between zero (no overlap) and 1 (complete overlap with the same UDs) (Fieberg \& Kochanny 2005).

\section{Recent changes in sea ice}

The distribution of walruses is closely associated with the distribution of sea ice. To summarize recent changes in the distribution of sea ice, we compared the proportions of open water and monthly sea ice concentrations during recent extreme summer ice minimums starting in 2007 (to 2011) (Wang \& Overland 2009) to a past $10 \mathrm{yr}$ period (1979 to 1988) starting with the earliest full-seasonal systematic satellite sea ice passive microwave imagery (Cavalieri et al. 1996, Meier et al. 2011).

We estimated the proportion of open water and sea ice concentration within the study area (Fig. 1) for each year of the 2007 to 2011 and 1979 to 1988 periods, using monthly (June to November) averages of daily or bi-daily ice concentrations within $25 \mathrm{~km} \times$ $25 \mathrm{~km}$ equal-area square pixels. A pixel was considered to have open water if the average ice concentration was $<15 \%$, the concentration at which sea ice can be reliably quantified by passive microwave sensors (Cavalieri et al. 1991). To estimate the proportion of open water in a month, we calculated the proportion of pixels that contained open water in that month. To estimate the concentration of sea ice in a month, we calculated the mean sea ice concentration across pixels that contained sea ice (i.e. those having a mean concentration $\geq 15 \%$ ) in that month. We derived a map of the general sea ice extent and con- centration in each month during each of the 2 periods, in which a pixel in the map indicates the median of the monthly mean ice concentration in that pixel across all years in the period. To compare the proportion of open water and ice concentration between periods, we summarized the median and range of yearly values within each period.

\section{RESULTS}

\section{Walrus radio-tagging}

We obtained tracking data from radio tags attached to 251 walruses Odobenus rosmarus divergens, mainly females (88\%) (Table 1, Fig. 2). We tagged walruses in offshore and onshore areas, primarily within the USA. The longevity of all tags across all years and deployment locations averaged about $5 \mathrm{wk}$ (Fig. 3). We obtained tracking data within Russian waters in June and July in the southwestern Chukchi Sea, because walruses tagged in the southern Chukchi Sea and Bering Straits region in June (2008 to 2010) (Table 1, Fig. 2) were migrating with the northward retreat of sea ice and many moved westward. Walruses tagged in the northeastern Chukchi Sea in July (2010 to 2011) (Table 1, Fig. 2) occupied sea ice in their northern feeding grounds in US waters and provided tracking data through August (Fig. 3), but

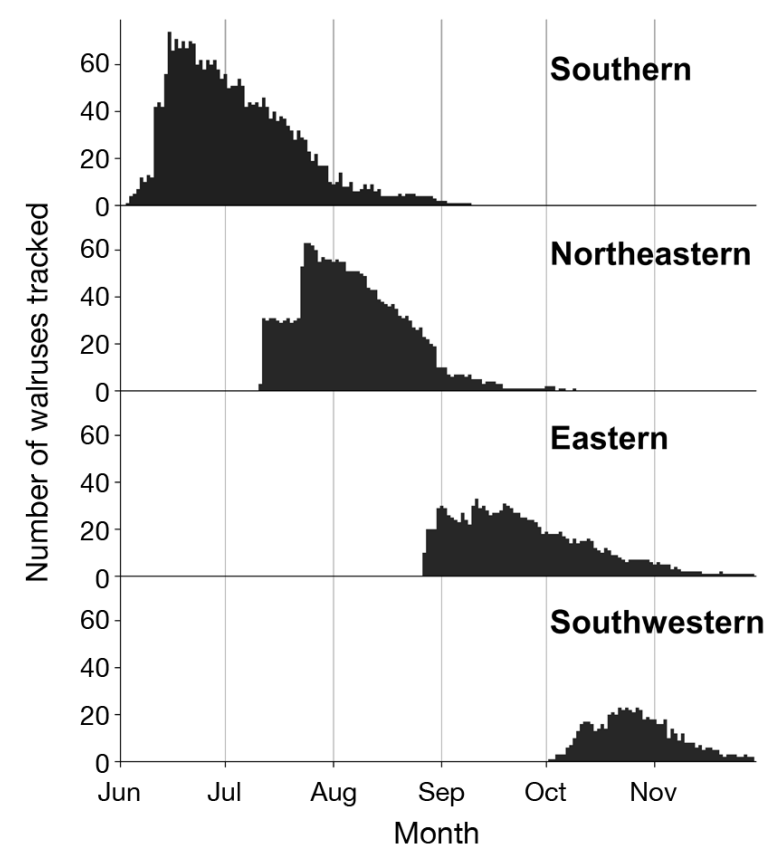

Fig. 3. Odobenus rosmarus divergens. Number of walruses tracked by deployment area in the Chukchi Sea, 2008 to 2011 (also see Table 1 and Fig. 2) 
only a small number of these walruses moved westward and into the northern waters of Russia during this period. Walruses tagged onshore in the eastern Chukchi Sea in late August and early September (2009 to 2011) (Table 1, Fig. 2) remained in US waters through much of September, then many moved into Russian waters in the southwestern Chukchi Sea in October. These walruses, and walruses tagged onshore in October (2010 to 2011) on the coast of northern Chukotka (Table 1, Fig. 2), provided tracking data in the southwestern Chukchi Sea in October and November (Fig. 3).

\section{Walrus areas of use relative to recent changes in sea ice}

Monthly UDs of walrus foraging and occupancy were estimated from 25 to 128 tagged walruses, which provided a mean duration of tracking ranging from 12 to $17 \mathrm{~d}$ among months (Table 2). UD estimates for November were derived from a smaller number of tracked walruses than in any other month.

The VI between foraging and occupancy UDs ranged from 0.88 to 0.96 , suggesting that walruses foraged in most of the areas they occupied (Table 2, Fig. 4). Lower VI indices occurred in August to October, months when the availability sea ice was often limited.

There were larger areas of open water and lower ice concentrations in the Chukchi Sea in all study months (June to November) in recent years (2007 to 2011) than in the past (1979 to 1988) (Figs. 5 \& 6). The difference in each of these months between periods in the median proportion of open water in the Chukchi Sea ranged from 0.14 to 0.59 , and the difference in each of these months between periods in the median sea ice concentration in the Chukchi Sea ranged from 10 to $41 \%$ (Fig. 6). These differences were greatest in August to October.

In June, as walruses migrated northward with the receding sea ice, their highest foraging concentrations were in an area offshore of the northeastern coast of Chukotka, along the northwestern coast of Alaska, and in the northeastern Chukchi Sea (Fig. 4). These foraging areas were in areas of low ice concentration within the ice margin along the Alaska nearshore flaw and along the developing flaw along the northern coast of Chukotka (Fig. 5). High ice concentrations probably restricted walruses from moving into areas north of the ice margin.

In July, the area of highest foraging concentration in the eastern Chukchi Sea was restricted to the
Table 2. Odobenus rosmarus divergens. Number of walruses and mean days of tracking among walruses used in monthly utilization distribution (UD) estimates of walrus foraging and occupancy in the Chukchi Sea from 2008 to 2011, and volume of intersection (VI) index between the UD of walrus foraging and occupancy. The VI index ranges between zero (no overlap) and 1 (complete overlap with the same UDs) (Fieberg \& Kochanny 2005). Some walruses contributed data to $>1 \mathrm{mo}$

\begin{tabular}{|lccccccc|}
\hline \multirow{2}{*}{ Month } & \multicolumn{5}{c}{ No. of walruses } & Tracking days, & VI \\
& 2008 & 2009 & 2010 & 2011 & Total & mean (min.-max.) & index \\
\hline Jun & 14 & 33 & 39 & 0 & 86 & $14.3(3-27)$ & 0.94 \\
Jul & 2 & 25 & 65 & 36 & 128 & $15.3(3-31)$ & 0.96 \\
Aug & 0 & 7 & 34 & 49 & 90 & $16.5(3-31)$ & 0.91 \\
Sep & 0 & 7 & 27 & 32 & 66 & $14.2(3-30)$ & 0.91 \\
Oct & 0 & 6 & 33 & 23 & 62 & $13.2(3-31)$ & 0.88 \\
Nov & 0 & 3 & 11 & 11 & 25 & $12.0(3-30)$ & 0.94 \\
\hline
\end{tabular}

northeastern sector (Fig. 4). Although less tracking data were available from the western Chukchi Sea in July, it was apparent that foraging occurred along the entire northern coast of Chukotka, in Long Strait, and to the northwest of Wrangel Island. Open water and low ice concentrations were more extensive in these areas in 2007 to 2011 than in 1979 to 1988 (Figs. $5 \& 6$ ).

In August, foraging occurred over a broader area than in July (Fig. 4), and the proportional overlap in areas of foraging and occupancy was lower than in previous months (Table 2). The distribution of walruses in August was influenced by a decrease in the availability of sea ice over the continental shelf (Fig. 5), particularly in the latter part of the month. Although open water was indicated by the satellite passive microwave imagery over much of the continental shelf in August, sparse and remnant sea ice was often present and undetected (i.e. below the $15 \%$ ice concentration detection limit of the imagery), as revealed by opportunistic comparisons to high-resolution MODIS images (http://modis.gsfc.nasa.gov/) and anecdotal observations from aircraft $\mathbf{1}$. In years when sea ice disappeared over the eastern Chukchi Sea shelf, walruses dispersed in different directions, including sometimes traveling through deep waters off the shelf, then back over the shelf shortly thereafter (Fig. 2). However, these excursions were infrequent and were associated with little to no foraging (Fig. 4). The movements of walruses in response to the sudden absence of sea ice over the shelf may be responsible, at least in part, for the areas where walruses occurred with little to no foraging activity.

\footnotetext{
$\underline{1}_{\text {www.afsc.noaa.gov/NMML/cetacean/bwasp/flights_COM }}$ IDA.php (accessed 18 April 2012)
} 

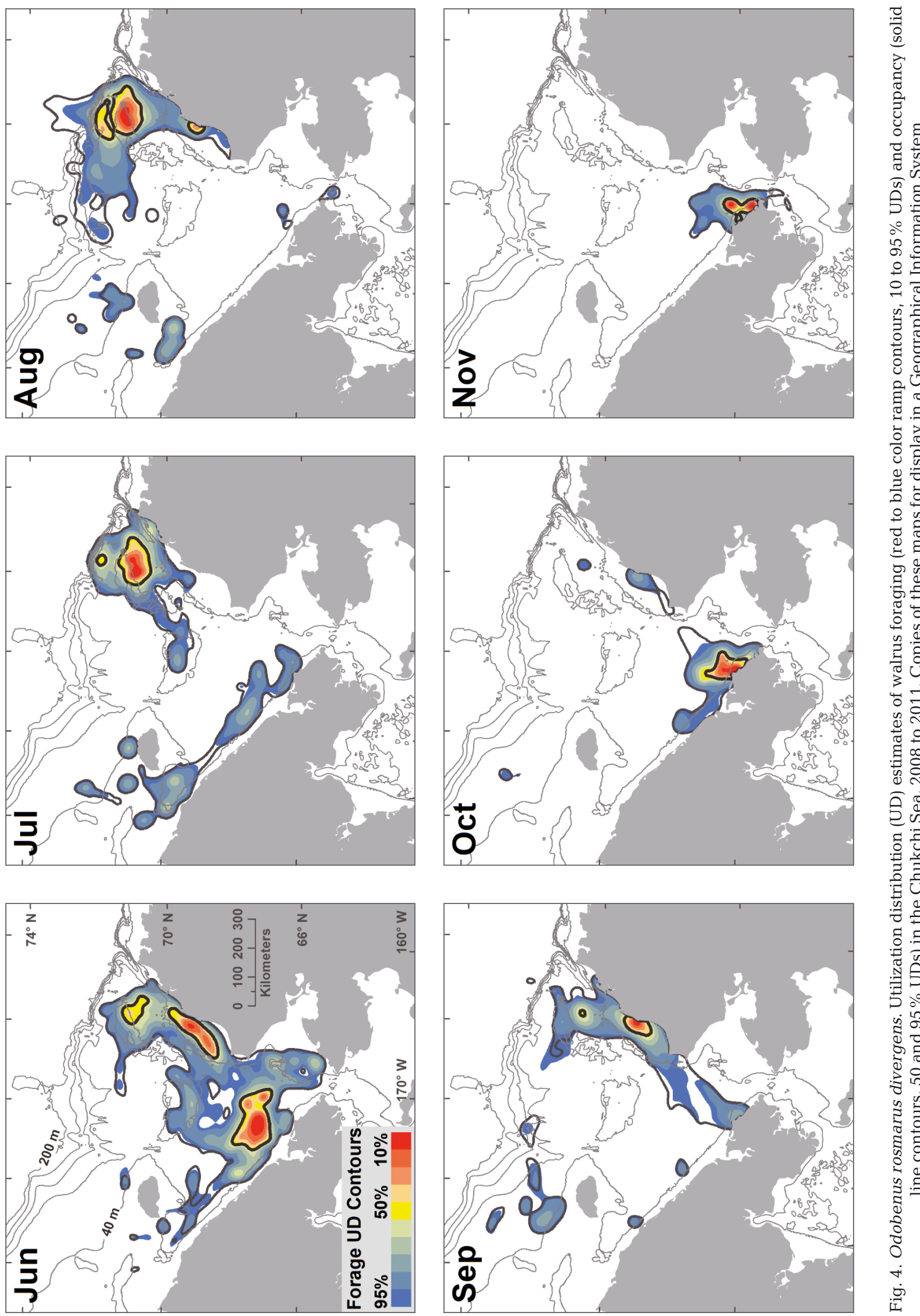


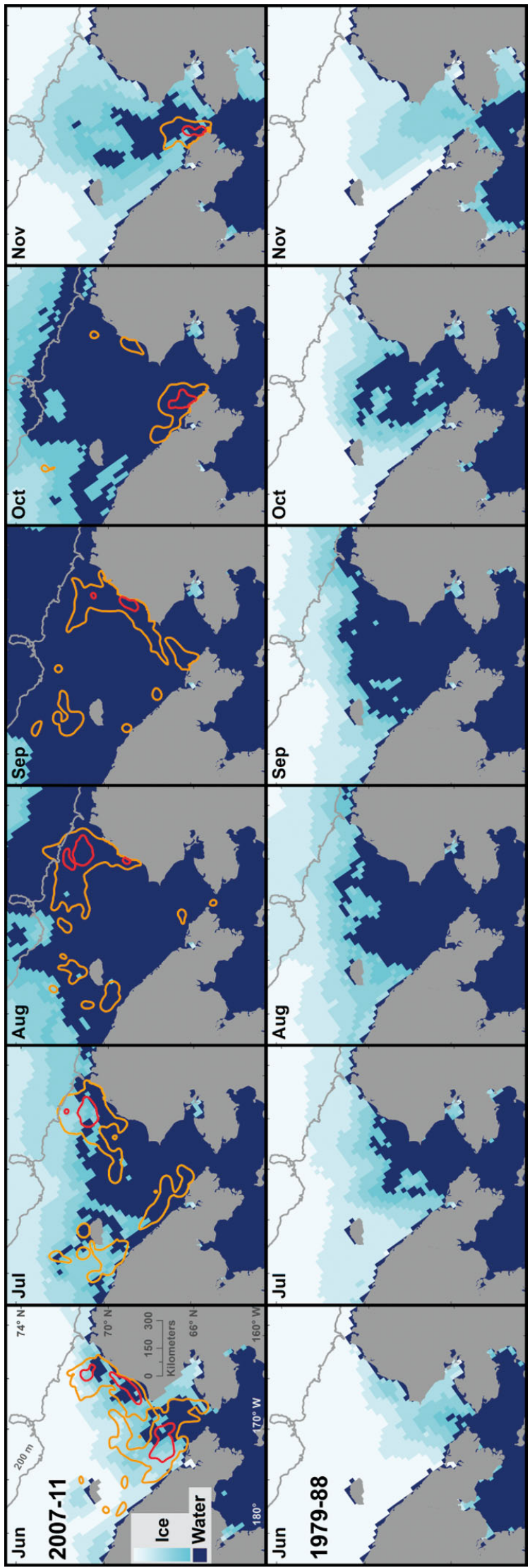

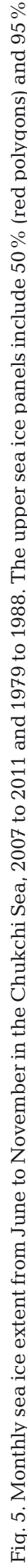
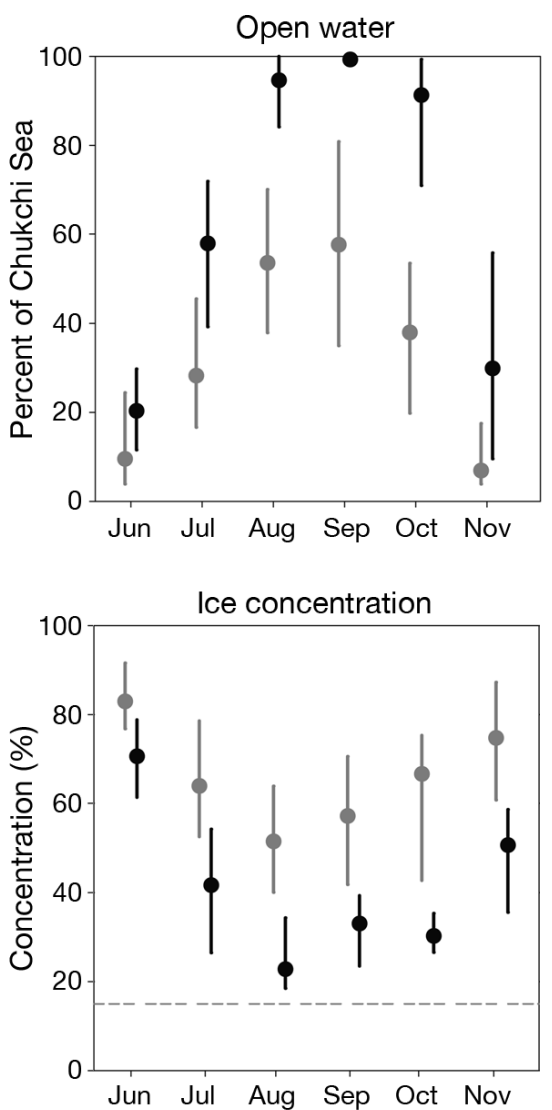

Fig. 6. Median (dot) and range (vertical line) of the yearly proportion of open water and ice concentration (in areas it occurred) in the study area (Fig. 1) from June to November 2007 to 2011 (black) and 1979 to 1988 (gray). The lower detection limit of sea ice concentration $(15 \%)$ is indicated by a gray dotted line

In September, foraging concentration was greatly reduced in the northeastern Chukchi Sea compared to August and shifted towards coastal areas of northwestern Alaska and northeastern Chukotka (Fig. 4), because many walruses hauled out on the coast after the disappearance of sea ice over the shelf. The small area of offshore foraging concentration we observed in the northeastern Chukchi Sea in September resulted from walruses traveling there from haul-outs on the coast of northwestern Alaska. Many walruses that were tagged on the northwest coast of Alaska in September eventually moved to the Chukotka coast by the end of October, and when they did, they often moved quickly and with little foraging activity within their migration corridor (Fig. 4). Sea ice sometimes occurred in northern areas of the western Chukchi Sea throughout summer and fall, which enabled walruses to maintain their locations offshore.

In October, walruses hauled out on the coast of northern Chukotka and foraged in a relatively small 
area in the southwestern Chukchi Sea (Fig. 4). The foraging distributions of walruses elsewhere in the western Chukchi Sea during this month are less clear.

In November, walruses continued to forage in the southwestern Chukchi Sea (Fig. 4). Large areas of open water and low sea ice concentrations remained in the southern Chukchi Sea during this month from 2007 to 2011, in contrast to past years when almost the entire Chukchi Sea had very little open water and was filled with a median sea ice concentration of $77 \%$ in November (Figs. 5 \& 6).

\section{DISCUSSION}

We observed a more northerly extension in the range of walruses Odobenus rosmarus divergens in the Chukchi Sea in June and July (Fig. 4) than has been depicted in maps of walrus distributions in the past (Fay 1982, Fay et al. 1984), which was coincident with recent increases in areas of open water and lower sea ice concentrations during these months. Furthermore, in September and October in 3 (2009, 2010, and 2011) of our 4 study years, walruses foraged in nearshore areas, in contrast to foraging in offshore areas in the past, because in recent years, sea ice disappeared over the continental shelf and caused young and adult female walruses to haul-out on shore in large numbers, a condition that did not commonly occur in the past (Fay et al. 1984).

In years when sea ice disappeared over the eastern Chuckchi Sea shelf in fall (2009, 2010, and 2011), walruses dispersed in different directions, but did not frequent the deep waters of the Arctic Basin. The small amount of foraging associated with some of the infrequent excursions of walruses off the shelf in August (Fig. 4) may have been falsely ascribed, because the walruses may have made deep navigational dives (e.g. Jay et al. 2001) and, therefore, met our prescribed time-at-depth foraging criterion that most of the sampled $1 \mathrm{~h}$ interval was spent below $10 \mathrm{~m}$ depth.

Additional changes in the distribution of walruses could occur in the future in response to further sea ice loss. Projections of sea ice extent from the Intergovernmental Panel on Climate Change models indicate that, in the Chukchi Sea, there will be extensive ice melt during July and ice-free conditions during August, September, and October by the end of the century, with sea ice melting 1 mo earlier in spring and beginning to freeze-up 2 mo later in fall (Douglas
2010, Wang et al. 2012). Walruses and substantial areas of open water occurred in the Chukchi Sea in November of our study, whereas, in the past, most walruses had passed south of the Bering Strait by this month (Fay et al. 1984). With increasing sea ice loss, it is likely that young and adult female walruses will occupy the Chukchi Sea for longer periods during the year and increase their use of coastal haul-outs and associated nearshore foraging areas (Jay et al. 2011).

Areas of concentrated walrus foraging generally corresponded to regions of high benthic biomass, such as in the northeastern (Hanna Shoal area) and southwestern Chukchi Sea (Dunton et al. 2005, Grebmeier et al. 2006). A notable exception was the occurrence of concentrated foraging in the nearshore area of northwestern Alaska. This area has low macroinfaunal biomass, a sandy substrate, and is dominated by the sand dollar Echinarachnius parma (Feder et al. 1994), which is not a typical prey item of walruses (Sheffield \& Grebmeier 2009). Walruses used this area in June during their northward migration in all study years, then again in late August and September during the period from 2009 to 2011, when sea ice completely disappeared over the continental shelf in the eastern Chukchi Sea. The reasons walruses selected this apparently depauperate area for use in August and September are unclear, and it seems unlikely that the area would adequately support the foraging demands of the large aggregations of walruses that occupied the area (e.g. >20 000 walruses in 2011, NOAA Chukchi Offshore Monitoring in Drilling Area aerial surveys) ${ }^{1}$. Notably, in 2009 and 2010, tagged walruses used the nearshore area immediately surrounding the onshore haul-out, but, in 2011, about half of the tagged walruses made round trips of up to about $200 \mathrm{~km}$ northward to an area just south of Hanna Shoal (USGS, Alaska Science Center, unpubl. data; see also September in Fig. 4), an area with high infaunal biomass of bivalves that was used extensively by walruses prior to September (Fig. 4). In contrast, in the past, offshore areas such as Hanna Shoal were utilized by walruses for the entire summer-fall period while using overshelf sea ice for hauling out (Fay 1982, Fay et al. 1984).

Although walruses foraged in most of the areas they occupied, we observed areas of low levels of foraging, which may have been related to traveling behavior, such as when they moved to find a haul-out substrate when sea ice disappeared over the shelf in August, moved from haul-out sites on the coast of northwestern Alaska to the coast of northern 
Chukotka in September and October, or moved between onshore haul-outs and offshore foraging areas at times during the period from August to October (Fig. 4). These periods of low levels of foraging, which are largely associated with the unavailability of offshore sea ice for walruses to use for hauling out, are likely to affect the level of energy reserves in the blubber of these walruses and their ability to compensate for energetic challenges that may occur in subsequent months. Walruses most vulnerable to altered activity patterns are likely to be lactating females and the young (Noren et al. 2012). Lactating females have double the energy demand of nonreproductive adult females and can only meet the elevated demand by utilizing the stored energy in the blubber. Walruses 2 to 5 yr of age may also be challenged, because they are weaned and have higher mass-specific energetic demands than adults (Noren et al. 2012). The energetic consequences of altered habitat use and activity patterns of walruses from decreased sea ice habitat in the Chukchi Sea are not fully understood.

Areas of walrus foraging in June to September (Fig. 5) overlap with the US Bureau of Ocean Energy Management oil and gas lease blocks within the Chukchi Sea Oil and Gas Lease Sale 193 (US Minerals Management Service 2009). The period of highest overlap between the lease sale area and areas of high walrus foraging concentration was in July and August. As the duration of ice-free periods in the Chukchi Sea increases in the future, other activities in the Chukchi Sea, such as ship and air traffic (Arctic Council 2009), are also likely to overlap walrus use areas in some months.

Tagging effort differed between the eastern and western sides of our study area. In US waters, we feel we obtained good spatial coverage of walrus movements and areas of use throughout the Chukchi Sea from June through October (most walruses moved to the southwestern Chukchi Sea by November). In Russian waters, we feel the spatial coverage of walrus movements we obtained was good in June, fair in July, weak in August and September, good in October (except perhaps in the northwestern areas), and good in November. Therefore, the relative concentration of walrus foraging and occupancy within our study area are biased towards the eastern side of our study area, particularly in July to September. Increased tagging in the western Chukchi Sea during these months would help better understand the timing of walrus movements and areas of foraging and occupancy in Russian waters.
Our study provides first-ever estimates of the relative concentration of walrus foraging throughout areas of the Chukchi Sea during a time of a rapid decrease in the extent, concentration, and thickness of summer sea ice (Kwok \& Rothrock 2009, Stroeve et al. 2011). The Pacific walrus is 1 of 8 ice-associated marine mammals in the Chukchi Sea experiencing changes to their Arctic environment (Moore \& Huntington 2008). The earlier and more extensive sea ice retreat in June to September and delayed freeze-up of sea ice in October and November created conditions for walruses to arrive earlier, occupy more northern areas of the continental shelf, stay later, and experience a longer period of ice-free conditions in the Chukchi Sea than in the past. The lack of sea ice over the continental shelf in September and October caused walruses to forage in nearshore areas in contrast to offshore foraging in the past. As walruses and other ice-associated marine mammals continue to respond to reductions in summer sea ice, they are likely to also be simultaneously exposed to increased human activities associated with further increases in the duration of seasonal ice-free periods in the Chukchi Sea.

While changes in sea ice can be predicted with some certainty (e.g. Douglas 2010, Wang et al. 2012), it is difficult to predict how these changes will affect walruses. The retreat of sea ice beyond the continental shelf in recent years represents a step change in summer habitat for the Pacific walrus, and our observations of their behavior under these conditions in the first 5 yr of extreme summer ice minimums provide a glimpse into their potential future response.

Acknowledgements. This project was supported by funds from the USGS, including the Changing Arctic Ecosystems initiative, contributed funds from the Northern Forum and Arctic Slope Regional Corporation (under Technical Assistance Agreement No. TAA08AK), and a grant from the North Pacific Research Board (NPRB Project No. 818). We appreciate field and logistical support from the Native Village of Pt. Lay (particularly from W. Harding Lampe, L. Ferreira III, M. Tracey, and B. Tracey Sr.), Vankarem (particularly from S. Kavry and V. Buchin), and Enurmino (particularly from S. Kabantsev), North Slope Borough, Eskimo Walrus Commission, and J. Garlich-Miller (USFWS). Field work in Russia was aided by A. Dondua, M. Chakilev (Pacific Research Fisheries Center, Chukotka Branch) and N. Kryukova (Russian Federal Research Institute of Fisheries and Oceanography). Excellent ship and air support were provided by the crew of RV 'Norseman II', and office and field staff from Olgoonik/Fairweather, LLC, Clearwater Air, and the NOAA COMIDA aerial survey program. Any use of trade names is for descriptive purposes only and does not constitute endorsement by the federal government. 


\section{LITERATURE CITED}

Arctic Council (2009) Arctic marine shipping assessment 2009 report. Arctic Council, Tromsø

Benhamou S, Cornélis D (2010) Incorporating movement behavior and barriers to improve kernel home range space use estimates. J Wildl Manag 74:1353-1360

Brueggeman JJ, Grotefendt RA, Smultea MA, Green GA and others (1992) Final report, Chukchi Sea 1991, marine mammal monitoring program (walrus and polar bear) Crackerjack and Diamond Prospects. Shell Western E\&P and Chevron USA, Anchorage, AK

Calenge C (2012) Home range estimation: Package 'adehabitatHR', V. 0.4.2. Office national de la classe et de la faune sauvage, Saint Benoist. Available at: http://cran.rproject.org/web/packages/adehabitatHR/adehabitatHR. pdf

Cavalieri DJ, Crawford JP, Drinkwater MR, Eppler DT, Farmer LD, Jentz RR, Wackerman CC (1991) Aircraft active and passive microwave validation of sea ice concentration from the defense meteorological satellite program special sensor microwave imager. J Geophys Res B 96:21989-22008

Cavalieri D, Parkinson C, Gloersen P, Zwally HJ (1996) (updated 2008) Sea ice concentrations from Nimbus-7 SMMR and DMSP SSM/I passive microwave data 1979-2007. National Snow and Ice Data Center, Boulder CO (digital media)

Collecte Localisation Satellites (2011) Argos user's manual. Collecte Localisation Satellites, Ramonville-Saint-Agne

Costa DP, Robinson PW, Arnould JPY, Harrison AL and others (2010) Accuracy of ARGOS locations of pinnipeds at-sea estimated using Fastloc GPS. PLoS ONE 5:e8677

Douglas DC (2010) Arctic sea ice decline: projected changes in timing and extent of sea ice in the Bering and Chukchi Seas. US Geological Survey Open-File Report 2010-1176: $1-32$

Douglas DC, Weinzierl R, Davidson SC, Kays R, Wikelski M, Bohrer G (2012) Moderating Argos location errors in animal tracking data. Methods Ecol Evol (in press) doi: 10.1111/j.2041-210X.2012.00245.x

Dunton KH, Goodall JL, Schonberg SV, Grebmeier JM, Maidment DR (2005) Multi-decadal synthesis of benthic-pelagic coupling in the western arctic: role of crossshelf advective processes. Deep-Sea Res II 52:3462-3477

Fay FH (1982) Ecology and biology of the Pacific walrus, Odobenus rosmarus divergens Illiger, Vol 74. US Department of the Interior, Fish and Wildlife Service, Washington, DC

Fay FH, Kelly BP (1989) Development of a method for monitoring the productivity, survivorship, and recruitment of the Pacific walrus population. Final report, OCS study, MMS 89-0012, Minerals Management Service, Anchorage, AK

Fay FH, Feder HM, Stoker SW (1977) An estimation of the impact of the Pacific walrus population on its food resources in the Bering Sea. PB-273-505, US Department of Commerce, National Technical Information Service, Springfield, VA

Fay FH, Kelly BP, Gehnrich PH, Sease JL, Hoover AA (1984) Modern populations, migrations, demography, trophics, and historical status of the Pacific walrus. In: Outer Continental Shelf Environmental Assessment Program: Final Rep 37. NOAA, US Department of Commerce, Washing- ton, DC, p 231-376

Feder HM, Naidu AS, Jewett SC, Hameedi JM, Johnson WR, Whitledge TE (1994) The northeastern Chukchi Sea: benthos-environmental interactions. Mar Ecol Prog Ser 111:171-190

Fieberg J, Kochanny CO (2005) Quantifying home-range overlap: the importance of the utilization distribution. J Wildl Manag 69:1346-1359

Fischbach AS, Jay CV, Jackson JV, Andersen LW, Sage GK, Talbot SL (2008) Molecular method for determining sex of walruses. J Wildl Manag 72:1808-1812

Grebmeier JM, Cooper LW, Feder HM, Sirenko BI (2006) Ecosystem dynamics of the Pacific-influenced northern Bering and Chukchi Seas in the Amerasian Arctic. Prog Oceanogr 71:331-361

Jay CV, Farley SD, Garner GW (2001) Summer diving behavior of male walruses in Bristol Bay, Alaska. Mar Mamm Sci 17:617-631

Jay CV, Heide-Jørgensen MP, Fischbach AS, Jensen MV, Tessler DF, Jensen AV (2006) Comparison of remotely deployed satellite radio transmitters on walruses. Mar Mamm Sci 22:226-236

Jay CV, Udevitz MS, Kwok R, Fischbach AS, Douglas DC (2010) Divergent movements of walrus and sea ice in the northern Bering Sea. Mar Ecol Prog Ser 407:293-302

Jay CV, Marcot BG, Douglas DC (2011) Projected status of the Pacific walrus (Odobenus rosmarus divergens) in the twenty-first century. Polar Biol 34:1065-1084

Kernohan BJ, Gitzen RA, Millspaugh JJ (2001) Analysis of animal space use and movements. In: Millspaugh JJ, Marzluff JM (eds) Radiotracking and animal populations. Academic Press, San Diego, CA, p 126-166

Kie JG, Matthiopoulos J, Fieberg J, Powell RA and others (2010) The home-range concept: Are traditional estimators still relevant with modern telemetry technology? Philos Trans R Soc Lond B Biol Sci 365:2221-2231

Kochnev AA (2004) Warming of eastern Arctic and present status of the Pacific walrus (Odobenus rosmarus divergens) population. In: Belkovich VM (ed) Proc Int Conf Marine Mammals of the Holarctic III, October 11-17, 2004, Koktebel, Crimea, Ukraine. Marine Mammal Council, Moscow, p 284-288

Kovacs KM, Lydersen C, Overland JE, Moore SE (2010) Impacts of changing sea-ice conditions on Arctic marine mammals. Mar Biodiversity 41:181-194

Kwok R, Rothrock DA (2009) Decline in Arctic sea ice thickness from submarine and ICESat records: 1958-2008. Geophys Res Lett 36:L15501, doi:10.1029/2009GL039035

Laidre KL, Stirling I, Lowry LF, Wiig O, Heide-Jorgensen MP, Ferguson SH (2008) Quantifying the sensitivity of Arctic marine mammals to climate-induced habitat change. Ecol Appl 18:S97-S125

Meier W, Fetterer F, Knowles K, Savoie M, Brodzik MJ (2011) (updated quarterly) Sea ice concentrations from Nimbus-7 SMMR and DMSP SSM/I passive microwave data, 2011. National Snow and Ice Data Center, Boulder, $\mathrm{CO}$ (digital media)

Moore SE, Huntington HP (2008) Arctic marine mammals and climate change: impacts and resilience. Ecol Appl 18:157-165

Noren SR, Udevitz MS, Jay CV (2012) Bioenergetics model for estimating food requirements of female Pacific walruses Odobenus rosmarus divergens. Mar Ecol Prog Ser 460:261-275 
Peterson WW, Brown DT (1961) Cyclic codes for error detection. Proc Inst Radio Eng 4:228-235

$>$ Polyak L, Alley RB, Andrews JT, Brigham-Grette J and others (2010) History of sea ice in the Arctic. Quat Sci Rev 29:1757-1778

Powell RA (2000) Animal home ranges and territories and home range estimators. In: Boitani L, Fuller TK (eds) Research techniques in animal ecology. Columbia University Press, New York, NY, p 65-110

Sheffield G, Grebmeier JM (2009) Pacific walrus (Odobenus rosmarus divergens): differential prey digestion and diet. Mar Mamm Sci 25:761-777

Stroeve JC, Serreze MC, Holland MM, Kay JE, Malanik J, Barrett AP (2011) The Arctic's rapidly shrinking sea ice cover: a research synthesis. Clim Change 110 1005-1027

Tynan CT, DeMaster DP (1997) Observations and predic- tions of Arctic climate change: potential effects on marine mammals. Arctic 50:308-322

Udevitz MS, Jay CV, Fischbach AS, Garlich-Miller JL (2009) Modeling haul-out behavior of walruses in Bering Sea ice. Can J Zool 87:1111-1128

US Minerals Management Service (2009) Environmental assessment, Shell Gulf of Mexico, Inc., 2010 exploration drilling program, Burger Crackerjack and SW Shoebill Prospects, Chukchi Sea Outer Continental Shelf, Alaska. OCS EIS/EA, MMS 2009-061. Minerals Management Service, US Dept of the Interior, Anchorage, AK

Wang M, Overland JE (2009) A sea ice free summer Arctic within 30 years? Geophys Res Lett 36:L07502, doi: 10.1029/2009GL037820

Wang M, Overland JE, Stabeno P (2012) Future climate of the Bering and Chukchi Seas projected by global climate models. Deep-Sea Res II 65-70:46-57

Appendix 1. Parameter settings for computations of the biased random-bridge-movement-based kernel density estimates

We computed the biased random-bridge (BRB) movement density estimator using the BRB function available in the $\mathrm{R}$ contributed package adehabitatHR, which is available through the Comprehensive $\mathrm{R}$ Archive Network (Calenge 2012). Prior to applying the BRB function, we estimated a diffusion coefficient for each month of each animal's track segments using maximum likelihood with the adehabitatHR BRB.likD function. We parameterized the BRB function with the following values: $T_{\max }=3 \mathrm{~d}$, $\tau=1 \mathrm{~h}, h_{\min }=16.5 \mathrm{~km}, L_{\min }=0.1 \mathrm{~m}$, and $b=$ TRUE. The BRB function relies on serially correlated locations to estimate utilization distributions (UDs), and the maximum time between locations within which locations may be considered correlated is set by the user with $T_{\max }$. To select a value for $T_{\max }$, we examined a plot of distance moved against time between successive locations of track segments from all walruses and years. The plot-indicated track segment distance approached a horizontal asymptote at about $4 \mathrm{~d}$. Therefore, we used a value of $3 \mathrm{~d}$ to indicate the time-to-independence of serial locations, and, hence, used only track segments with durations of $\leq 3 \mathrm{~d}$ to estimate UDs. To enable weighting of UDs based on telemetered activity, in our case hourly foraging status, the BRB function interpolates a variable number of locations between the recorded locations based on the magnitude of the telemetered activity, the time elapsed between recorded locations, and a user-selected temporal interpolation interval, $\tau$. We selected $\tau$ to be the same as the interval over which the radio tags summarized foraging status (i.e. $1 \mathrm{~h}$ ). The BRB function requires an estimate of the minimum kernel smoothing bandwidth $\left(h_{\min }\right)$, which
Benhamou \& Cornélis (2010) recommend setting to the sum of the minimum standard deviation of the location accuracy and the half interval length of the maximum animal transit speed that may be sustained during the track segment intervals. Locations used in this study had a mean Argos location quality of 2, which Costa et al. (2010) estimated to have a mean error of $1000 \mathrm{~m}$ for locations estimated from tags transmitting from pinnipeds offshore. To estimate the maximum walrus transit speed that may be sustained during a $24 \mathrm{~h}$ tracking interval, we used the 99th percentile of displacement speeds observed over daily tracking intervals by Jay et al. (2010), which was reported to be $1.25 \mathrm{~km} \mathrm{~h}^{-1}$. Thus, we parameterized $h_{\min }$ to be $1000 \mathrm{~m}+\left(1250 \mathrm{~m} \mathrm{~h}^{-1} \times 24 \mathrm{~h} / 2\right)=16000 \mathrm{~m}$. In selecting the minimum number of track segments to be considered from a walrus in a study month, we sought to allow all tracking data collected from each walrus during each study month, but were constrained by the minimum number of track segments that could be processed by the BRB.likD function, which was 3 segments. We allowed the $\mathrm{BRB}$ function to progressively merge relocation variance with the interpolated movement variance by setting the $b$ parameter to TRUE. The BRB function may be set to override recorded activity status when the animal track indicates no movement during a track segment by setting a minimum distance (parameter $L_{\min }$ ) below which track segments are considered to be inactive. We set $L_{\text {min }}$ to be arbitrarily low, less than the $1 \mathrm{~m}$ resolution of our tracking locations, to ensure that the BRB function would always use the recorded activity when weighting track segments. 